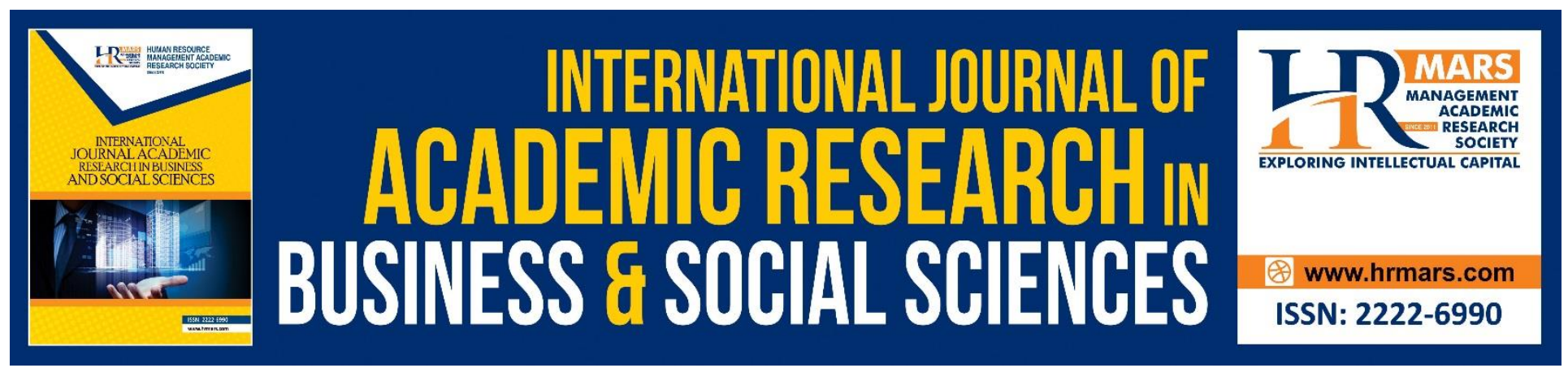

\title{
The Importance of Inclusive Education Course for Preparing Pre-Service Teacher to Teach Students with Special Needs in School
}

Norfishah Mat Rabi, Nor Hasnida Che Md Ghazali, Grace Annammal Ghana
Piragasam

To Link this Article: http://dx.doi.org/10.6007/IJARBSS/v8-i11/5360

DOI: $10.6007 /$ IJARBSS/v8-i11/5360

Received: 05 Nov 2018, Revised: 03 Dec 2018, Accepted: 06 Dec 2018

Published Online: 09 Dec 2018

In-Text Citation: (Rabi, Ghazali, \& Piragasam, 2018)

To Cite this Article: Rabi, N. M., Ghazali, N. H. C. M., \& Piragasam, G. A. G. (2018). The Importance of Inclusive Education Course for Preparing Pre-Service Teacher to Teach Students with Special Needs in School.

International Journal of Academic Research in Business and Social Sciences, 8(11), 1848-1858.

\section{Copyright: (C) 2018 The Author(s)}

Published by Human Resource Management Academic Research Society (www.hrmars.com)

This article is published under the Creative Commons Attribution (CC BY 4.0) license. Anyone may reproduce, distribute, translate and create derivative works of this article (for both commercial and non-commercial purposes), subject to full attribution to the original publication and authors. The full terms of this license may be seen

at: http://creativecommons.org/licences/by/4.0/legalcode

Vol. 8, No. 11, 2018, Pg. 1848 - 1858

http://hrmars.com/index.php/pages/detail/IJARBSS

JOURNAL HOMEPAGE

Full Terms \& Conditions of access and use can be found at http://hrmars.com/index.php/pages/detail/publication-ethics 


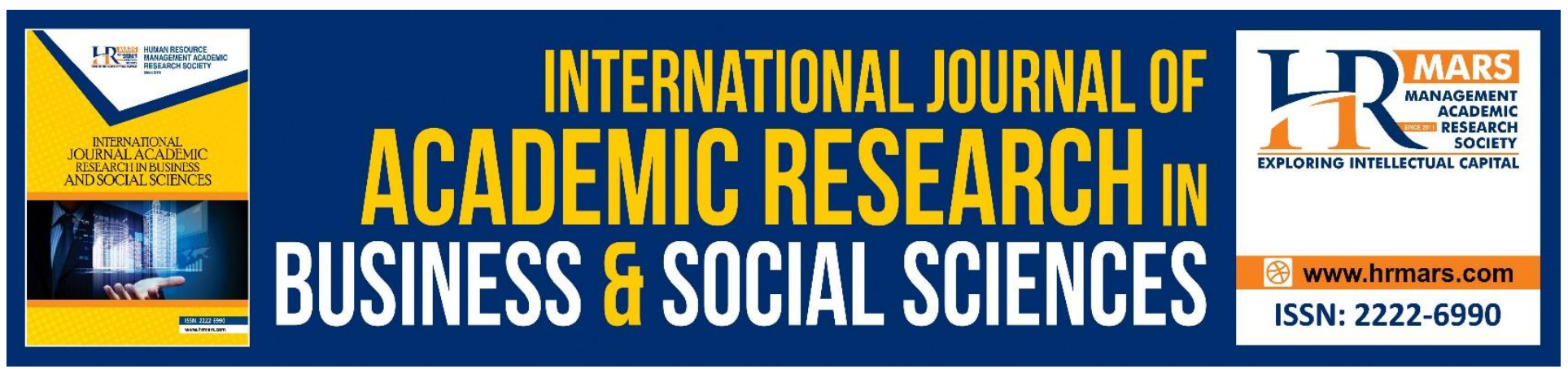

\title{
The Importance of Inclusive Education Course for Preparing Pre-Service Teacher to Teach Students with Special Needs in School
}

\author{
Norfishah Mat Rabi ${ }^{1}$, Nor Hasnida Che Md Ghazali², Grace \\ Annammal Ghana Piragasam ${ }^{3}$ \\ Faculty of Human Development, Universiti Pendidikan Sultan Idris, Malaysia
}

\begin{abstract}
The purpose of this study is to investigate the importance of the Inclusive Education (KPK 3012) course for preparing pre-service teachers at Universiti Pendidikan Sultan Idris (UPSI) to teach students with special education needs in schools. The four objectives of the study are based on the outcome of the course learning which is to identify the importance of teaching aspects of the characteristics of special needs students, inclusive education policies, attitudes concerned and teaching techniques. his case study was conducted at UPSI involving 30 pre-service teachers. The data collection period is for four months. Data collection methods used are observation, interviews and document analysis. The observation was conducted five times during KPK 3012 course lectures. Two sets of interview questions were set up and used in four interview sessions. The findings show that this course can provide respondents with knowledge about the characteristics of special needs students, inclusive education policies, attitudes concerned and teaching techniques. Research implications indicate that an inclusive education course can provide pre-service teachers with the knowledge and skills required by teaching students with special educational needs. Inclusive education courses should be offered at all institutions with educational programs to enable potential teachers to teach special needs students in the future.
\end{abstract}

Keywords: Inclusive Education, Pre-Service Teacher, Special Needs

\section{Introduction}

Teaching special needs is a challenging task for first-line teachers. The mainstream teacher should have sufficient knowledge, skills and experience to teach special needs students in an inclusive class. In order for the mainstream teachers to teach students with special needs, they need to have an early readiness before being instructed to teach at school. The willingness of teachers to teach special needs can be trained through inclusive-related training or courses. An inclusive education courses can provide guidance and examples of how teachers can improve their practice and must be in line 
with the practice of teachers to effectively teach student with special needs (Boyle, Topping, \& JindalSnape, 2013; Florian dan Linklater (2010). This is because teachers' education courses focusing on inclusive issues have transformed self-perception and efficacy as well as providing basic knowledge to students towards inclusive education (Killoran, Woronko, \& Zaretsky, 2014; Loreman, Sharma, \& Forlin, 2013).

Teaching an inclusive education course is important to help pre-service teachers be prepared for teaching special needs in school. In Malaysia, the government makes Inclusive Education as one of the nation's development agenda (PPPM, 2013). This indicates that all schools that provide the Integrated Education Program (IEP) must implement Inclusive Education (IE) to the pupils at the school. In preparation for teaching IP programs, teachers and potential teachers should have the willingness to teach special needs students in school. Preparation of MBK's pre-service teacher in an inclusive program needs to be done before they graduate. It is important to provide teachers with the knowledge, skills and understanding of inclusive so they can play an effective role in school (Sharma, Simi \& Forlin, 2015).

\section{Literature Review}

Inclusive education is an educational program provided to children with special needs along with the mainstream students. They are integrated into a class or classroom in the same setting and learn the same curriculum. Inclusive according to Lewis and Doorlag (2011) is a place where students with special needs learning alongside mainstream students in the same setting. Caldwell (2010) finds that the benefits of full inclusive programs are that students can improve development in social and academic aspects. When in the same setting, student with special needs has the opportunity to create effective communication and interaction with peers.

A study conducted by Shahazadi (2000) on the perspective of inclusive education found that teachers, administrators, professionals and parents had knowledge of the concept of inclusive education but were uncertain about how it would be implemented effectively. This is the cause of inclusive education less successful. By having adequate training, the attitude of teachers teaching inclusive programs is more efficient. But what happens is that most teachers who teach students with special needs do not have systematic specific training. This is evidenced in the study by Boyle et. al, (2013) found that $68 \%$ of teachers did not have the qualifications in Special Education. This study suggests that inclusive education policies should be consistent with the practice of teachers to effectively teach. Proposals are also made on the importance of effective inclusive education at the teacher training level. Based on the various issues that occur in inclusive education, efforts are needed to address the problems affecting the implementation of inclusive education. According to Armstrong, et al. (2010) curriculum adjustment needs to be made for students with special needs to be absorbed in an inclusive program.

To prove the importance of this inclusive education course, studies have been conducted by Killoran, Woronko, \& Zaretsky (2014) on the existing teacher education courses and their impact on the attitude of teachers in inclusive education. The key focus is on inclusive issues in existing inclusive programs to explore the trust of prospective teachers and existing assumptions on inclusive programs. Florian and Linklater (2010) studies emphasize the importance of developing a course that can provide guidance and examples of how teachers can enhance more inclusive practices. Rational 
theory for course development is outlined and examples of how teachers may be involved in more inclusive practice. Inclusive strategies taught to pre-service teachers are insufficient to enhance positive attitudes, effectiveness of teaching, or reduce anxiety without associating it with a broader context of inclusive education (Sharma, Simi and Forlin, 2015). The findings of Killoran et al., (2014) show that inclusive education courses have successfully changed the perception of pre-service teachers on inclusive programs and provide a solid foundation of knowledge to be practiced in future teaching.

Preparation of pre-service teacher training in an inclusive class needs to be done carefully. The study by Sharma, Simi and Forlin (2015) uses four indicators to identify the readiness of preservice teachers through the consideration of four attitudes, efficacy, concerns and interests of preservice teachers teaching an inclusive class. An effective way to improve the attitude of pre-service teachers to the inclusive is to ensure they are given opportunities along with special needs students (Chambers \& Lavery, 2012; Forlin, 2003; Forlin \& Chambers, 2011), learning about inclusive education policies and policies (Armstrong et al., 2010) and received support for inclusive education at school (Loreman et al., 2013). The knowledge and skills acquired in the course help prepare pre-service teacher readiness in an inclusive program.

Pre-service teachers pursuing inclusive education courses have succeeded in forming a more positive attitude toward special needs students in an inclusive class. The attentive attitude of successful preservice teachers is to gain knowledge about how to collaborate with special education teachers, communication skills with students, know about support services and so on. Even research by Sharma and Nuttal (2016) proved through courses taken, attitudes and efficacy of pre-service teachers increased while their concerns decreased significantly and the level of concern for pre-service teachers who did not know the disabled had decreased.

Experience interacting with people with disabilities and collaborative practices based on mutual trust and commitment to teamwork should be thoroughly studied by pre-service teachers, providing effective teachers in inclusive programs requires system workshops and support for teachers (Loreman, Sharma, \& Forlin 2013; Philpot, Furey \& Penney, 2010; Walton et al., 2014). Preservice teachers should also know about the services of various government agencies, medical and therapeutic services, social support services, and private agency services and non-governmental organizations.

\section{Methodology}

The design of this study is based on a case study. This study examines specifically on the teaching of Inclusive Education (KPK 3012) course to UPSI pre-service teacher (PST) as a preparation to teach students with special needs (SSN) in an inclusive program. This study uses purposive sample. The sample of the study is 30 pre-service teachers (UPSI students Semester 1 to Semester 8) who take KPK 3012 courses and 2 lecturers who teach KPK 3012 courses at UPSI. Participants of regular lecturers and pre-service teachers are not from the Special Education field.

For data collection, this case study uses interviews, observations and document analysis. An interview session was conducted to obtain qualitative data. Interviews were conducted individually with Respondents Lecturers (ResL), and focus groups with pre-service teacher respondents (ResPST). Observation is carried out during teaching and learning activities. Observation was conducted five 
times. Instruments used in collecting data are checklists, field notes, and video recordings. Four checklists are used as a data collection tool that is a Special Needs Student Characteristics Checklist (SNSC), Inclusive Education Policy Checklist (IEP), Teaching Method Checklist (TM), and Checklist on Attitude (AC). Documents referenced are Course Framework (CF), Teaching Design (ID), lecture notes, and assignments. This case study was analyzed and reported descriptively and supported by reference statistics.

\section{Results}

The findings refer to the importance of the Inclusive Education Course (IEC) offered to UPSI's preservice teachers in four main areas: (i) characteristics of students with special needs, (ii) teaching techniques, attitudes concerned towards special needs students, and (iv) inclusive education policies.

The characteristics of students with special needs in IEC

The importance of this course is based on the content of the Course Framework (CF) for learning outcomes describing the characteristics of special needs students. The findings of the observation score are based on the checklist marked by the survey participants during the observation session. Table 1 shows the findings of PST's knowledge on the characteristics of students with special needs.

Table 1. Characteristics of students with special needs

\begin{tabular}{|c|c|l|c|c|c|}
\hline No & Code & Student with special needs characteristic & \multicolumn{3}{|c|}{ Score } \\
\cline { 3 - 5 } & & & Yes & Unsure & No \\
\hline 1 & DLI & Definition of low incidence & 20 & 7 & 3 \\
\hline 2 & TLI & Type of low incidence & 20 & 7 & 3 \\
\hline 3 & VI & Visual impairment & 27 & 3 & 0 \\
\hline 4 & HI & Hearing impairment & 28 & 2 & 0 \\
\hline 5 & POH & Physical and other health problem & 30 & 0 & 0 \\
\hline 6 & DHI & Definitions of high incidence & 20 & 5 & 5 \\
\hline 7 & THI & Type of high incidence & 20 & 6 & 4 \\
\hline 8 & ASD & ASD / Autisme & 20 & 8 & 2 \\
\hline 9 & DS & Down Syndrome & 30 & 0 & 0 \\
\hline 10 & DYS & Dyslexia & 22 & 6 & 2 \\
\hline 11 & ADHD & ADHD & 24 & 7 & 2 \\
\hline 12 & GNT & Gifted and talented & 22 & 5 & 3 \\
\hline 13 & MDD & Multiple disability definition & 25 & 3 & 2 \\
\hline 14 & DB & Deaf-blind & 329 & 64 & 27 \\
\hline & & & 78.33 & 14.24 & 6.43 \\
\hline & & & & 5 \\
\hline
\end{tabular}

Table 1 shows that $78.33 \%$ of participants support the Inclusive Education (IEC) course to help them understand the characteristic of student with special needs. $15.24 \%$ of participants are unsure while $6.43 \%$ agreed that the course was not important to them. From the 14 subtopics studied, result 
INTERNATIONAL JOURNAL OF ACADEMIC RESEARCH IN BUSINESS AND SOCIAL SCIENCES

Vol. 8, No. 11, Nov, 2018, E-ISSN: 2222-6990 @ 2018 HRMARS

showed the highest score were for other physical and health problems $(\mathrm{POH})$ and down syndrome (DS). While the lowest score is knowledge of the definition of low incidence (DHI), type of low incidence (TLI), definitions of high incidence (DHI), type of high incidence (THI), and ASD / Autism.

Teaching techniques in IEC

The findings show that IEC are crucial in helping pre-service teachers (GPP) learn about teaching techniques for special education students in inclusive education programs at schools. Table 2 shows the findings of interest in teaching techniques.

Table 2. Teaching techniques in IEC

\begin{tabular}{|c|c|l|c|c|c|}
\hline No & Code & Teaching techniques & \multicolumn{3}{|c|}{ Score } \\
\cline { 3 - 5 } & & & Yes & Unsure & No \\
\hline 1 & TnL & Teaching and learning & 30 & 0 & 0 \\
\hline 2 & AESA & $\begin{array}{l}\text { Assessment and evaluation of student } \\
\text { achievement }\end{array}$ & 25 & 4 & 1 \\
\hline 3 & CMH & $\begin{array}{l}\text { Communication methods of hearing } \\
\text { impairment students }\end{array}$ & 18 & 7 & 5 \\
\hline 4 & SHI & $\begin{array}{l}\text { Use of Software in the Teaching and } \\
\text { Learning Process of Hearing Impaired } \\
\text { Students }\end{array}$ & 25 & 5 & 0 \\
\hline 5 & $\mathrm{Br}$ & Braille & 10 & 10 & 10 \\
\hline 6 & $\mathrm{OA}$ & $\begin{array}{l}\text { Optical and Non-Optical assistance tool for } \\
\text { restricted visionary students }\end{array}$ & 15 & 7 & 8 \\
\hline 7 & ICT & ICT for visual impaiment students & 23 & 5 & 2 \\
\hline 8 & AEM & Assessment and evaluation model & 26 & 3 & 3 \\
\hline 9 & IEP & Individual Education Plan & 27 & 3 & 0 \\
\hline & & & 199 & 44 & 29 \\
\hline & & & 73.16 & 16.18 & 10.66 \\
\hline
\end{tabular}

Table 2 shows the importance of teaching IEC on the aspects of teaching techniques. The findings show that $73.16 \%$ participants agreed that the IEC help them be prepared in teaching student with special needs. $16.18 \%$ of participants said they were unsure and $10.66 \%$ of participants said the course did not give importance to them. $100 \%$ of participants agree that IEC are important for them to learn about teaching and learning $(T n L)$ techniques in an inclusive class. Teaching Braille subtitles were found to have the lowest score in which only 10 participants agreed the IEC helped them prepare to teach student with visually impaired.

Attitudes concerned in IEC

The preparation to teach student with special needs is also seen in the context of teaching aspects of attitudes of concern. Pre-service teachers needs to gain knowledge, experience and skills in student with special needs in the classroom. Attitudes are concerned with the need to be nurtured 
INTERNATIONAL JOURNAL OF ACADEMIC RESEARCH IN BUSINESS AND SOCIAL SCIENCES

Vol. 8, No. 11, Nov, 2018, E-ISSN: 2222-6990 @ 2018 HRMARS

and this course can help the preparation of pre-service teachers to teach student with special needs with appropriate attitudes. Table 3 shows the importance of teaching aspects of attitudes in the IEC.

Table 3. Attitudes concerned in IEC

\begin{tabular}{|c|c|l|c|c|c|}
\hline No & Code & \multicolumn{1}{|c|}{ Attitudes concern } & \multicolumn{3}{c|}{ Score } \\
\cline { 3 - 5 } & & \multicolumn{1}{|c|}{ Yes } & Unsure & No \\
\hline 1 & SCS & Social and communication skills & 28 & 2 & 0 \\
\hline 2 & CSE & $\begin{array}{l}\text { Collaboration with special education } \\
\text { teachers }\end{array}$ & 27 & 6 & 1 \\
\hline 3 & VIP & $\begin{array}{l}\text { Vision and Implication Problems in } \\
\text { Education }\end{array}$ & 25 & 3 & 2 \\
\hline 4 & SS & Support Services & 27 & 1 & 2 \\
\hline 5 & GAS & Government Agency Services & 26 & 3 & 1 \\
\hline 6 & MTS & Medical and Therapeutic Services & 23 & 1 & 2 \\
\hline 7 & SSS & Social Support Services & 22 & 6 & 2 \\
\hline 8 & NGO & $\begin{array}{l}\text { Private Agency Services and Non } \\
\text { Governmental Organizations }\end{array}$ & 21 & 5 & 4 \\
\hline & $\quad$ Total & 195 & 29 & 16 \\
\hline & & Percentage $\%$ & 81.25 & 12.08 & 6.67 \\
\hline
\end{tabular}

Table 3 shows the findings of the attitude concern in teaching in an inclusive class. Overall, $81.25 \%$ of participants acknowledged the importance of this course towards their preparation to teach student with special needs. $12.08 \%$ of participants were unsure whether this course is important to them while $6.67 \%$ of participants agreed that IEC is not important to them. The highest score is the importance of social and communication skills (SCS). While 21 participants said the course had an interest in the aspect of the services of private agencies and non-governmental organizations (NGO) and obtained the lowest score in this study. Collaboration with special education teachers (CSE) and support services (SS) are two subtopics of interest to learn.

Inclusive education policies in IEC

The importance of teaching policies of inclusive education is also given attention in this study. There are nine sub-topics that have the interest to be taught to PST as a preparation to teach in an inclusive program. Table 4 shows the importance of this course in the inclusion of inclusive education policy. 
INTERNATIONAL JOURNAL OF ACADEMIC RESEARCH IN BUSINESS AND SOCIAL SCIENCES

Vol. 8, No. 11, Nov, 2018, E-ISSN: 2222-6990 @ 2018 HRMARS

Table 4. Inclusive education policy in IES

\begin{tabular}{|c|c|l|c|c|c|}
\hline No & Code & \multicolumn{1}{|c|}{ Inclusive education policies } & \multicolumn{3}{|c|}{ Score } \\
\cline { 3 - 5 } & & & Yes & Unsure & No \\
\hline 1 & CIE & $\begin{array}{l}\text { Concept and definition of Inclusive } \\
\text { Education }\end{array}$ & 27 & 3 & 0 \\
\hline 2 & NIE & Needs to Inclusive Education & 25 & 5 & 0 \\
\hline 3 & IEM & $\begin{array}{l}\text { Inclusive education model in typical } \\
\text { education }\end{array}$ & 27 & 3 & 0 \\
\hline 4 & TIE & Types of Inclusive Education & 27 & 3 & 0 \\
\hline 5 & FIE & Fully Inclusive Education & 30 & 0 & 0 \\
\hline 6 & SIE & Partially Inclusive Education & 30 & 0 & 0 \\
\hline 7 & IEM & $\begin{array}{l}\text { Inclusive Education Management at } \\
\text { Schools }\end{array}$ & 22 & 6 & 2 \\
\hline 8 & IES & Inclusive education settings & 25 & 4 & 1 \\
\hline 9 & WNP & Welfare and needs of inclusive pupils & 26 & 2 & 2 \\
\hline & & Total & 249 & 26 & 5 \\
\hline & & $\quad$ Percentage \% & 88.92 & 9.29 & 1.79 \\
\hline
\end{tabular}

Table 4 shows the importance of teaching education policies. Overall, $88.93 \%$ of participants agreed that the course was important for them to master the knowledge on inclusive education policies. 9.29\% of participants are not sure whether this course is important to them while $1.79 \%$ of participants think this course does not importance to them. The findings show that aspects of fully inclusive education (FIE) and partially inclusive education (PIE) achieve the highest score while the inclusive education management at school (IEM) achieves the lowest score. From the course, respondents understand better in inclusive education policies in Malaysia as a preparation to teach student with special needs in school.

\section{Discussion}

The importance of the Inclusive Education course in this study found that the four importance of learning this course is about the characteristics of special needs students, special needs teaching techniques, attitudes toward special needs students, and inclusive education policies. Although teachers have no qualification in Special Education, they can learn about Special Education based on the module so they can teach more effectively in inclusive classes (Boyle et al, 2013; In Gennaro et al., 2014). The inclusive education policy should be consistent with the practice of teachers in order to teach effectively. The importance of implementing inclusive education effectively should be made at the level of teacher training by developing courses that can provide guidance and examples of how teachers can enhance more inclusive practices and inculcate inclusive attitudes (Boyle et al, 2013; Florian \& Linklater, 2010; Philpot , Furey \& Penney, 2010). Walton, Nel, Muller and Lebeloane (2014) also emphasize the need for professional learning to be nurtured in professional life and teacher work to achieve meaningful teaching goals (Philpot, Furey and Penney (2010).

Knowledge of students' special needs is one of the important aspects in cultivating the willingness of teachers to teach in an inclusive class. Professional development should provide 
teachers with the skills to identify and define special needs problems, recognize their students and understand the importance of learning the culture of students, and knowledge about disability needs (Florian, 2012; Jenkins \& Yoshimura, 2010; Nichols \& Sheffield, 2014; Philpot, Furey \& Penney, 2010). In order to improve the pre-service teacher's attitude towards inclusive, they should be given the opportunity together with special needs students (Chambers \& Lavery, 2012) so that they can understand and understand the characteristics of the students in depth.

This study proves that the teaching of the topic of inclusive education is crucial for preparing pre-service teacher teaching special needs. The course provides a solid foundation of inclusive knowledge to be practiced in future teaching. In the case of inclusive education policy, pre-service teachers study various aspects of inclusive education, the concept and definition of inclusive education, the need for inclusive education, the inclusive education model in special education, the types of inclusive education, the full-time inclusive education, the part-time inclusive education , inclusive education management in schools, an inclusive classroom layout (setting), and the welfare and needs of inclusive students. Teacher education courses focusing on inclusive issues have transformed perceptions and self-efficacy also provided basic knowledge to students towards inclusive education (Killoran, Woronko, \& Zaretsky, 2014, Loreman, Sharma, \& Forlin, 2013). Teacher preparation programs provided by teacher training institutions should provide a full range of knowledge on inclusive education laws and policies (Philpot, Furey \& Penney, 2010). experience interacting with people with disabilities, the level of confidence in teaching disabled, and previous teaching and training experiences with disabilities (Loreman, Sharma, \& Forlin, 2013).

The importance of KPK 3012 courses is also seen in the teaching of teaching techniques. Through this course pre-service teachers study various topics related to teaching techniques for students with special needs. Pre-service teachers introduced a variety of teaching media for special needs students such as optical and non-optical devices, Braille, various software, and ICT for students with special needs. As a prospective teacher who will teach students with special needs, it is important that pre-service teachers are prepared with knowledge regarding teaching techniques. Education officials and decision-makers should think whether teachers need to know how to improve teaching and learning, or innovate in teaching and should be exposed to various teaching strategies, including developing a record of assessment and using cognitive strategies to improve learning (Florian, 2012; Lancaster \& Bain, 2010; Philpot, Furey \& Penney, 2010). Group-based teaching strategies such as cooperative learning and peer-tutoring, support or multidisciplinary groups to facilitate student learning (Garrote, Sermier, \& Moser, 2017). Such activities will encourage critical thinking skills, creative thinking skills, communication skills, and collaborative learning skills of students with special needs with other students. Teacher education courses should align teaching methods equally with inclusive values and support the way teachers deal with complex features in the context of the 21st century education (Di Gennaro et al., 2014). So this study is very much in keeping with the purpose of providing a pre-service teacher with special needs teaching with the right teaching techniques in an inclusive class. 
INTERNATIONAL JOURNAL OF ACADEMIC RESEARCH IN BUSINESS AND SOCIAL SCIENCES

Vol. 8, No. 11, Nov, 2018, E-ISSN: 2222-6990 @ 2018 HRMARS

\section{Conclusion}

The teaching of inclusive education courses is crucial in preparing pre-service teachers to teach inclusive classes. Knowledge and skills on the characteristics of students with special needs, inclusive education policies, teaching techniques, and attitudes should be given priority in providing preservice teachers with special needs. It is recommended that this inclusive education course be offered to pre-service teachers at universities offering educational programs so that they are also willing to teach inclusive programs.

\section{Acknowledgement}

The authors would like to express utmost appreciations to the Research Management and Innovation Center (RMIC) for the allocation of the Research Grant University.

\section{Corresponding Author}

Norfishah Mat Rabi,

Faculty of Human Development, Universiti Pendidikan Sultan Idris,

Malaysia

Email: norfishah@fpm.upsi.edu.my

\section{References}

Armstrong, A.C., Armstrong, D. \& Spandagou, I. (2010). Inclusive education: International policy and practice. London: Sage Publications.

Boyle, C.,Topping, K., \& Jindal-Snape, d. (2013). Teachers' attitudes towards inclusion in high schools. Teachers and Teaching Theory and practice. 19(5), 527-542.

Chambers, D. J., \& Lavery, S. D. (2012). Service-learning: A valuable component of pre service teacher education. Australian Journal of Teacher Education, 37(4).

Di Gennaro, D. C., Pace, E. M. \& Iolanda, Z. \& Aiello, Z. (2014). Teacher capacity building through critical reflective practice for the promotion of inclusive education. Problems of Education in the 21st Century, 60, 54-65.

Florian, L. \& Linklater, H. (2010). Preparing teachers for inclusive education: using inclusive pedagogy to enhance teaching and learning for all. Cambridge Journal of Education. 40 (4), 369-386.

Florian, L. (2012). Teacher education for inclusion. In C. Forlin (Ed.), Future Directions for Inclusive Teacher Education (pp. 212-220). Oxon, UK.: Routledge.

Forlin, C. (2003). Pre-service teacher education: Involvement of students with intellectual disabilities. International Journal of Learning. 10, 317-326

Garrote, A., Sermier Dessemontet, R., Moser Opitz, E. (2017). Facilitating the social participation of pupils with special educational needs in mainstream schools: A review of school-based interventions. Educational Research Review, Vol. 20, No. 1, 12-23.

Jenkins, A. \& Yoshimura, J. (2010). Not another in-service! Meeting the special education profesional development needs of elementary general educators. Teaching Exceptional Children (May/June), 36-43.

Killoran, I., Woronko, D. \& Zaretsky, H. (2014). Exploring pre service teachers' attitudes towards inclusion. International Journal of Inclusive Education, 18(4), 427-442. 
Lancaster, J. \& Bain, A. (2010). The design of pre-service inclusive education courses and their effects on self-efficacy: A comparative study. Asia-Pacific Journal of Teacher Education, 38(2), 117-128.

Lewis, R.B. \& Doorlag, D. H. (2011). Teaching students with special needs in general education classrooms. 8th Ed. New Jersey: Pearson Education, Inc.

Loreman, T., Sharma, U., \& Forlin, C. (2013). Do pre-service teachers feel ready to teach in inclusive classrooms? A four-country study of teaching self-efficacy. Australian Journal of Teacher Education, 38 (1), Article 3. Available at: http://ro.ecu.edu.au/ajte/vol38/iss $1 / 3$ http://dx.doi.org/10.14221/ajte.2013v38n1.10

Nichols, S. C. \& Sheffield, A. N. (2014). Is there an elephant in the room? Considerations that administrators tend to forget when facilitating inclusive practices among general and special education teachers. National Forum of Applied Educational Research Journal, 27(1\&2), 31-44.

Philpot, D. F., Furey, E. \& Penney, S.C. (2010). Promoting leadership in the ongoing profesional development of teachers: Responding to globalization and inclusion. Exceptionality Education International 20(2), 38-54

Sharma, U. (2011). Changing heart, head, and hands of teachers to teach in inclusive classrooms: Why and how? Bangladesh Education Journal, 10(2), 7-18.

Sharma, U., Forlin, C., Deppeler, J., \& Guang-xue, Y. (2012). Reforming teacher education for inclusion in developing countries in the Asia Pacific Region, Asian Journal of Inclusive Education, 3-16.

Sharma, U., Simi, J., \& Forlin, C. (2015). Preparedness of Pre-service Teachers for Inclusive Education in the Solomon Islands. Australian Journal of Teacher Education, 40(5).

Walton, E., Nel, N.H., Muller, H. \& Lebeloane, O. (2014). You can train us until we are blue in our faces, we are still going to struggle: Teacher professional learning in a full-service school. Education as Change, 18(2), 319-333. 